\title{
Peningkatan Mutu Pembelajaran Melalui Supervisi Akademik Berdasarkan Mutu Standar Proses Pembelajaran
}

\author{
Alfajri Amri \\ 17086355 \\ Email : alfajriamri48@gmail.com
}

\begin{abstract}
Abstrak
Banyak usaha yang telah dilakukan pemerintah untuk meningkatkan mutu pendidikan di sekolah, seperti menerbitkan Peraturan Pemerintah RI Nomor 19 tahun 2005 tentang Standar Nasional Pendidikan. Institusi pendidikan juga tidak ketinggalan dengan mengadakan kegiatan ilmiah yang dapat mengembangkan potensi guru melalui seminar, pelatihan, workshop dan lainnya secara berkelanjutan sehingga guru menjadi profesional yang mempunyai kemampuan meningkatkan mutu pembelajaran di sekolah yang pada akhirnya peningkatan mutu pendidikan akan terwujud dan menjadi kenyataan. Artikel ini membahas faktor-faktor peningkatan mutu pendidikan, unsur-unsur peningkatatan mutu pendidikan serta strategi peningkatan mutu pendidikan.
\end{abstract}

Kata Kunci : Mutu Pendidikan

\section{LATAR BELAKANG}

Kondisi pendidikan di Indonesia sampai sekarang ini masih rendah dikarenakan rendahnya kualitas sumber daya manusia di Indonesia. Rendahnya kualitas sumber daya manusia ini disebabkan oleh mutu pendidikan di Indonesia yang masih rendah. Pendidikan merupakan suatu kegiatan interaksi antara peserta didik dengan para pendidik serta berbagai sumber pendidikan yang berlangsung dalam situasi pendidikan, pengajaran, latihan serta bimbingan. Agar pencapaian hasil pembelajaran maksimal, maka dibutuhkan sosok guru yang professional. Hal itu dikarenakan dalam dunia pendidikan khususnya bagian pengajaran, tolak ukur keberhasilannya adalah guru. Namun, sering kali banyak faktor yang menghambat guru-guru dalam mengembangkan berbagai potensinya secara optimal, Oleh karena itu, supervisi pendidikan sangat diperlukan bagi para guru agar pekerjaan yang dilakukan oleh guru bisa berjalan sesuai dengan ketentuan.

Berdasarkan uraian diatas, permasalahan dalam tulisan ini adalah (1) Bagaimana Pelaksanaan supervisi pendidikan oleh Kepala Sekolah sebagai Supervisor? (2)Bagaimana implementasi/penerapan supervisi pendidikan dalam meningkatkan proses pembelajaran di sekolah? Tujuan tulisan ini adalah untuk mengetahui bagaimana implementasi/penerapan supervisi pendidikan dalam meningkatkan proses pembelajaran di sekolah. 


\section{Pembahasan}

Pendidikan merupakan faktor utama dalam pembentukan pribadi manusia. Oleh karena itu, pemerintah sangat serius menangani pendidikan dan berusaha terus untuk peningkatan mutu pendidikan, sebab dengan sitem pendidikan yang baik diharapkan muncul generasi penerus bangsa yang berkualitas dan mampu mengadakan perubahan kearah yang lebih baik dalam kehidupan bermasyarakat berbangsa dan bernegara.

Setiap satuan pendidikan melakukan perencanaan proses pembelajaran, pelaksanaan proses pembelajan, penilaian hasil pembelajaran, dan pengawasan proses pembelajaran untuk terlaksananya proses pembelajaran yang aktif dan dinamis.Undang-undang dan Peraturan pemerintah tersebut mengindikasikan tentang pentingnya memperhatikan mutu pembelajaran guna meningkatkan mutu pendidikan di sekolah.Dalam rangka meningkatkan mutu pendidikan tersebut pada tahun 2005 pemerintah mengeluarkan Peraturan RI nomor 19 tahun 2005 tentang Standar Nasional Pendidikan, peraturan ini merupakan usaha pemerintah untuk meningkatkan mutu pendidikan di Indonesia.

Menurut (Sabandi, 2013) supervisi seharusnya dilakukan untuk menjamin pembelajaran yang berkualitas, karena terdapat hubungan langsung antara kinerja guru dengan prestasi belajar siswa. Dalam artian, semakin tinggi kinerja guru maka semakin tinggi prestasi belajar siswa,

Menurut (Suryani, 2016) , maka harus mempu melakukan berbagai pengawasan dan pengendalian untuk meningkatkan proses belajar mengajar. Pengawasan dan pengendalian merupakan kontrol agar kegiatan pendidikan di sekolah terarah sesuai tujuan yang telah ditetapkan. Pengawasan dan pengendalian juga merupakan tindakan pencegahan (preventive) agar para guru tidak melakukan penyimpangan dan lebih berhati-hati dalam melaksanakan tugasnya.

Menurut (Lazwardi, 2016) masih sering menemui kendala diantaranya pengadaan calon supervisor yang kurang tepat. Cara terbaik dalam pengadaan calon kepala sekolah atau supervisor pada orang-orang yang sudah berpengalaman menjadi guru dan memiliki keahlian sebagai sebagai kepala sekolah atau supervisor. Supervisi memerlukan kerativitas tinggi dari pada supervisor untuk mencari solusi dari problem yang ada di lapangan. Belum banyak supervisor yang memiliki kreativitas tinggi dalam memecahkan masalah. Disinilah pentingnya supervisor meningkatkan kompetensi secara maksimal, sehingga ia mampu mengembangkan gaya berpikir yang kreatif, kritis, inovatif dan produktif. Rendahnya kualitas lembaga pendidikan akan berdampak pada kualitas guru dan kualitas guru yang berada dibawah standar akan membawa pengaruh besar pada peserta dedik. Supervisor yang berkualitas adalah supervisor yang dapat memberikan bantuan kepada guru ke arah usaha pemecahan masalah dan perbaikan kualitas proses pembelajaran secara sistematis, berkelanjutan dan komprehensif.

\section{Kesimpulan}

Dalam rangka meningkatkan mutu pendidikan di sekolah telah diupayakan melalui berbagai kegiatan penataran, seminar, pendidikan pelatihan ataupun workshop. Melalui berbagai kegiatan tersebut dikenalkan pada inovasi- inovasi pembelajaran, karena inovasi adalah sebagai suatu kebutuhan. Pengembangan bahan ajar, pengembangan strategi dan metode pembelajaran, pengembangan media pembelajaran, sistem penilaian, evaluasi, dan esesmen telah menjadi menu utama dunia pendidikan, tetapi dari pengalaman empirik tampaknya upaya-upaya itu belum secara signifikan membawa perubahan dalam arti peningkatan mutu pendidikan di sekolah.

Oleh sebab itu yang harus dilakukan adalah perbaikan yang berkesinambungan berkaitan dengan komitmen (Continuos quality Improvement) dan proses Continuous pross Improvement. Komitmen terhadap kualitas dimulai dengan pernyataan dedikasi pada misi dan visi bersama, serta pembedayaan 


\section{REFERENSI}

Lazwardi, D. (2016). IMPLEMENTASI SUPERVISI PENDIDIKAN DI SEKOLAH/MADRASAH. Jurnal Kependidikan Islam, 6(1), 22. https://doi.org/https://doi.org/10.24042/alidarah.v6i1.794

Sabandi, A. (2013). Supervisi Pendidikan Untuk Pengembangan Profesionalitas Guru Berkelanjutan. Pedagogi, Jurnal Ilmiah Ilmu Pendidikan, XIII(2), 1-9. Retrieved from http://ejournal.unp.ac.id/index.php/pedagogi/article/view/4275

Suryani, C. (2016). Implementasi Supervisi Pendidikan Dalam Meningkatkan Proses Pembelajaran Di Min Sukadamai Kota Banda Aceh. Jurnal Ilmiah Didaktika, 16(1), 23. https://doi.org/10.22373/jid.v16i1.585 